\title{
RECOVERY OF LEAD AND NOBLE METALS AFTER PROCESSING PRINTED CIRCUIT BOARDS FROM CELL PHONES BY LEACHING WITH MIXTURES CONTAINING HYDROGEN FLUORIDE
}

\author{
Walner Costa Silva ${ }^{a}$, Roger de Souza Corrêaa ${ }^{a}$ Pedro Rosário Gismontia , Júlio Carlos Afonso ${ }^{\mathrm{a} *}$, Rubens Souza da Silva \\ Cláudio Augusto Vianna ${ }^{\mathrm{b}}$ and José Luiz Mantovano ${ }^{\mathrm{b}}$ \\ aDepartamento de Química Analítica, Instituto de Química, Universidade Federal do Rio de Janeiro, 21941-909 Rio de Janeiro \\ - RJ, Brasil \\ bDepartamento de Química e Materiais Nucleares, Instituto de Engenharia Nuclear, 21941-906 Rio de Janeiro - RJ, Brasil
}

Recebido em 28/05/2018; aceito em 16/07/2018; publicado na web em 31/07/2018

\begin{abstract}
This work examines the leaching of printed circuit boards (PCBs) from cell phones in aqueous solutions containing $\mathrm{HF}+\mathrm{H}_{2} \mathrm{O}_{2}$ or $\mathrm{HF}+\mathrm{NaClO}$ under mild experimental conditions. The PCBs were not ground but were previously treated with $6 \mathrm{~mol} \mathrm{~L}^{-1} \mathrm{NaOH}^{2}$ $50{ }^{\circ} \mathrm{C}$ for $1 \mathrm{~h}$ to remove their soldering mask. The $\mathrm{HF}+\mathrm{H}_{2} \mathrm{O}_{2}$ mixtures leached copper and base metals (except lead) at $35-40{ }^{\circ} \mathrm{C}$, leaving a solid residue containing lead and noble metals. Leaching was fastest $(1 \mathrm{~h})$ when $\mathrm{HF}$ and $\mathrm{H}_{2} \mathrm{O}_{2}$ concentrations were at least $5 \mathrm{~mol} \mathrm{~L}^{-1}$ and $3 \mathrm{~mol} \mathrm{~L}^{-1}$, respectively. The processing of the solid residue is also described in detail. It was leached with water at $\sim 90{ }^{\circ} \mathrm{C}$ followed by $\mathrm{HNO}_{3 a q}$ at $25^{\circ} \mathrm{C}$. Lead, palladium and silver were recovered in this order, leaving gold as final solid. After $1 \mathrm{~h}$ at $35-40{ }^{\circ} \mathrm{C}, 5 \mathrm{~mol} \mathrm{~L}-1 \mathrm{HF}+0.3 \mathrm{~mol} \mathrm{~L}^{-1} \mathrm{NaClO}$ mixtures leached the base metals, copper, gold and palladium. Gold was recovered by liquid-liquid extraction with methyl isobutyl ketone. Silver precipitated as chloride. This salt was isolated by leaching with $\mathrm{NH}_{3 a q}$. Loss of fluoride ions (as HF) was below $0.5 \mathrm{wt}$ \% after leaching and handling the solid residue.
\end{abstract}

Keywords: PCB; metals recovery; acidic leaching; gold; silver; hydrofluoric acid.

\section{INTRODUCTION}

With advancements in the electronic world almost occurring on a day-to-day basis and increased availability of products to the public, the production of electrical and electronic equipments (EEE) has been one of the fastest-growing sectors both in industrialized and industrializing countries. At the same time, the average lifetime of electronic products has also been drastically reduced due to rapid increase in demand of advanced products. Consequently, it is not surprising to see a staggering increase of Waste Electrical and Electronic Equipments (WEEE or "e-waste") over the past decades. ${ }^{1-4}$ The current global production of WEEE is expected to increase rapidly at an alarming rate of 20-25 million tons per year, ${ }^{4,5}$ with an estimated growth rate going from $3 \%$ up to $5 \%$ per year. ${ }^{6-8}$

This fast obsolescence makes the linear 'extraction-productionusage-disposal' chain even more resource-intensive, increasing, therefore, their impacts on environment, human health and economy. This scenario is aggravated by the peculiarities of WEEE: they contain more than a thousand different substances, many of which are high-valued or highly toxic. ${ }^{9}$ As this waste is a potential source of valuable materials, it has been called an "urban ore ${ }^{5,8,10}$ and recycling of the printed circuit boards (PCBs) represents the most economically attractive portion of WEEE. ${ }^{2,11}$ Handling and treatment of WEEE is a topic of worldwide concern. ${ }^{3}$ However, only about $15 \%$ of the scrap PCBs are subject to any kind of recycling. ${ }^{12}$

The mobile phone is widely utilized as an integrated telecommunication and information equipment. ${ }^{13}$ The life of the mobile phone is getting reduced drastically (2-3 years). Hence, a copious mobile phone waste of more than 8.2 billion objects is expected to be accumulated worldwide in the coming years. ${ }^{7}$ The composition of a PCB from a cell phone varies from model to model of each brand. Its basic structure is the copper-clad laminate consisting of glass-reinforced epoxy resin and a number of metallic materials. ${ }^{7,11,12}$

*e-mail: julio@iq.ufrj.br
The elements in mobile phones may be categorized as precious metals ( $\mathrm{Au}, \mathrm{Ag}$ ), platinum group metals (Pd, Pt, Rh, Ir and $\mathrm{Ru}$ ), base metals ( $\mathrm{Cu}, \mathrm{Al}, \mathrm{Ni}, \mathrm{Sn}, \mathrm{Zn}$ and $\mathrm{Fe}$ ), hazardous metals ( $\mathrm{Hg}, \mathrm{Be}, \mathrm{Pb}, \mathrm{Cd}$, As and $\mathrm{Sb}$ ), scarce or trace elements (In, Te, Ga, Se, Ta and Ge). ${ }^{7} \mathrm{PCBs}$ from cell phones contain copper, silver, gold and palladium in higher concentrations than their respective ores. ${ }^{2,4,5,12}$ From an economic perspective, recycling mobile phones is very attractive. . $^{7,14,15}$

About $30 \%$ of gold, $20 \%$ of palladium and $12 \%$ of silver come from secondary sources. ${ }^{7,16,17}$ Yet, the fact that such a highly complex concoction of various valuable and sometimes hazardous materials are intermingled in such a small volume poses serious engineering challenges for the recovery and recycling of the constituent materials. The heterogeneous mix of organics, metals, fiber glass and plastics makes the PCB processing a challenging task, ${ }^{3}$ and is the main barrier in the recovery of metals from scraps. ${ }^{8,14}$

In a typical recycling line of waste PCBs, physical processing operations such as grinding, sieving, magnetic, electrostatic, gravity separations and density-based separation are applied as pretreatments to liberate and concentrate the metallic fractions (MFs) and nonmetallic fractions (NMFs). ${ }^{1}$ A great deal of dust and poisonous gas are produced during crushing, sieving, dissolved air flotation etc. In general, a well-designed recycling line must be equipped with dusting system and waste gases disposal system. ${ }^{5}$

Increasing attention on precious metals recovery such as gold, silver and platinum from waste PCBs (WPCBs) has boosted the development of new processes including physical ${ }^{18-20}$ and thermochemical techniques. ${ }^{12,18,19,21}$ Hydrometallurgical methods are one of the key technologies in metal recycling because they enable a fine separation between chemically-similar metals in small-scale operation. ${ }^{1,22-26}$ The base metals recovery has a substantial impact on the economics of the process due to larger available amount in WPCBs. ${ }^{27}$ Moreover, previous leaching of base metals ensures the enrichment of precious metals in the solid residue, making it easier to leach out subsequently. ${ }^{11}$ Acidic leaching has been investigated with inorganic acids $\left(\mathrm{HCl}, \mathrm{H}_{2} \mathrm{SO}_{4}, \mathrm{HNO}_{3}, \mathrm{HClO}_{4}\right)$. As metals in 
WPCBs are present in native and/or alloy form, the development of oxidative leaching processes using an oxidant such as $\mathrm{H}_{2} \mathrm{O}_{2}, \mathrm{O}_{2}$ and $\mathrm{Fe}^{3+}$ is required. ${ }^{1,14,25,26} \mathrm{In}$ order to avoid the possible interference of copper, it is strongly necessary to dissolve this metal before gold leaching. ${ }^{13}$ Some leaching processes have been developed to recover copper from WPCBs for their high leaching selectivity to date, the leaching system including nitric acid, ammoniacal sulfate and chloride solution. ${ }^{18,28}$

Cyanide, thiourea, halide, and thiosulfate have been the most common leaching agents for the recovery of precious metals of PCBs from mobile phones. Although cyanide is very efficient, it is very toxic. ${ }^{29,30}$ Many studies have been performed to replace it. ${ }^{14,24,31,32}$

In spite of dynamic research on this field, many of the processes have not reached commercial-scale operation due to various drawbacks, such as great energy consumption and large amount of waste acid liquid produced during the processes. The flow of recycling metals in waste $\mathrm{PCBs}$ may be long and complicated due to poor selectivity of inorganic acids as leaching agents, leading to a high recovery cost. ${ }^{2,11,33}$

This work describes a novel hydrometallurgical process to recover valuable metals of PCBs from cell phones under mild experimental conditions on lab-scale using an oxidant in acidic medium. The PCBs were not ground. Hydrofluoric acid was used as leachant taking advantage of its complexing properties. This acid reacts with many base metals because fluoride is a very hard base and forms very stable complexes with cations with noble gas-like configuration (the so-called hard acids). This is generally found in cations with a high charge and a small ionic radius, like $\mathrm{Al}^{3+}$, $\mathrm{Sn}^{4+}$ and $\mathrm{Fe}^{3+}$. Furthermore, it rapidly dissolves silicon dioxide and silicates as very stable $\left[\mathrm{SiF}_{6}\right]^{2-}$ ions are produced. ${ }^{34,35}$ Therefore, this acid reacts with the PCB laminate (ceramic/fiberglass components), thus increasing exposition of metals to the leachant. The leachates and the insoluble matter were chemically characterized to determine the effect of some experimental parameters on leaching and to develop a suitable scheme for recovery of noble metals from the insoluble matter.

\section{EXPERIMENTAL}

\section{PCB samples}

Thirty PCBs from the same model and brand were collected from the inventory of obsolete components at a dismantling WEEE unit. These PCBs were kept in their original form (i.e. they were not ground).

\section{Processing of the PCBs}

\section{First step: removal of the soldering mask}

The first step was the removal of the transparent thin polymeric film (typically, 25-250 $\mu \mathrm{m}$ thickness) which protects the board's components against moisture, dust, chemicals, and extreme temperatures. ${ }^{36}$ This coating does not allow leaching of metals present in PCBs. ${ }^{37,38}$ Taking into account that epoxy resins are frequently used as coatings, ${ }^{37,39}$ the $\mathrm{PCBs}$ were immersed in $6 \mathrm{~mol} \mathrm{~L}^{-1} \mathrm{NaOH}(10 \mathrm{~mL}$ $\left.\mathrm{g}^{-1} \mathrm{PCB}\right)$ in a Teflon beaker at $50{ }^{\circ} \mathrm{C}$ for $1-4 \mathrm{~h}$ under stirring (100 rotations per minute). After this treatment the $\mathrm{PCB}$ was removed with plastic tweezers and washed with water $\left(5 \mathrm{~mL} \mathrm{~g}^{-1}\right)$, dried at $25^{\circ} \mathrm{C}$ and weighed. A fine greenish-milky solid deposited at the bottom of the beaker. It was filtered, washed with water $\left(3 \mathrm{~mL} \mathrm{~g}^{-1}\right)$, dried at $25^{\circ} \mathrm{C}$ and weighed. This solid was placed in a ceramic crucible and calcined in a furnace $\left(600^{\circ} \mathrm{C}, 3 \mathrm{~h}\right)$. The roasted mass was cooled down in the furnace and weighed.
Second step: chemical leaching $\left(\mathrm{HF}+\mathrm{H}_{2} \mathrm{O}_{2}\right.$ or $\left.\mathrm{HF}+\mathrm{NaClO}\right)$

All leaching experiments were carried out in a fume hood (face velocity $0.5 \mathrm{~m} \mathrm{~s}^{-1}$ ) in $250 \mathrm{~mL}$ closed Teflon vessels. HF (40 wt. \%, $\sim 20 \mathrm{~mol} \mathrm{~L}^{-1}$ ), $\mathrm{H}_{2} \mathrm{O}_{2}$ (30 wt. \%, $10 \mathrm{~mol} \mathrm{~L}^{-1}$ ) and $\mathrm{NaClO}$ (6 wt.\%, $\left.\sim 0.8 \mathrm{~mol} \mathrm{~L}^{-1}\right)$ were of analytical grade and were used as received without further purification. Handling of these reactants was performed using appropriate personal protective equipment (chemical splash goggles together with a face shield, neoprene rubber gloves that cover the hands, wrists, and forearms and a laboratory coat). The initial experiments were performed combining equal volumes of $\mathrm{HF}$ and oxidant (therefore, the leachants contain $\sim 10 \mathrm{~mol} \mathrm{~L}^{-1} \mathrm{HF}$ and $\sim 5 \mathrm{~mol} \mathrm{~L}^{-1} \mathrm{H}_{2} \mathrm{O}_{2}$ or $\sim 0.4 \mathrm{~mol} \mathrm{~L}-1 \mathrm{NaClO}$ ). Time varied from 1 to $4 \mathrm{~h}$. The solid/liquid ratio was fixed at $10 \mathrm{~mL}$ leachant $\mathrm{g}^{-1} \mathrm{PCB}$. Initial temperature was $25^{\circ} \mathrm{C}$. Stirring was fixed at 200 rotations per minute. In a second set of experiments the effect of $\mathrm{HF}$ and oxidant concentrations was studied. Distilled water was added to adjust concentration of one or both reactants prior to mixing them. The remaining experimental conditions were kept as such.

After adding the treated PCB to the leachant, temperature increased by $15{ }^{\circ} \mathrm{C}$ after $\sim 1 \mathrm{~h}$ in the presence of $\mathrm{H}_{2} \mathrm{O}_{2}$. Temperature decreased to $\sim 30{ }^{\circ} \mathrm{C}$ at the end of the experiment. No thermal effect was observed when $\mathrm{NaClO}$ was the oxidant. Therefore, its experiments were slowly heated during $1 \mathrm{~h}$ to $\sim 40{ }^{\circ} \mathrm{C}$, after which temperature was slowly decreased to $\sim 30^{\circ} \mathrm{C}$ at the end of the experiment. The vessel was opened at $25{ }^{\circ} \mathrm{C}$. The PCB was removed using plastic tweezers, washed with water $\left(3 \mathrm{~mL} \mathrm{~g}^{-1}\right)$ and dried at $25^{\circ} \mathrm{C}$. Then, it was ground in a knife mill to a size fraction below $0.2 \mathrm{~mm} .{ }^{40}$ The insoluble matter consisted of the components released from the PCBs (resistors, relays, connectors, chips etc.) and a fine solid. The leachate was passed through a plastic sieve $(0.5 \mathrm{~mm})$ in order to retain the PCB components, which were washed with water $\left(6 \mathrm{~mL} \mathrm{~g}^{-1}\right.$ processed PCB). The washings and the filtrate were combined and filtered (under vacuum) through an ordinary quantitative filter paper. The fine solid was washed with water $\left(4 \mathrm{~mL} \mathrm{~g}^{-1}\right.$ processed PCB), dried at $110{ }^{\circ} \mathrm{C}$ for $2 \mathrm{~h}$ and weighed. The following equations describe the possible reactions between copper, lead, tin, noble metals, aluminum, iron and silicon dioxide with $\mathrm{HF}$ and the oxidative leachants with values of $\Delta \mathrm{G}^{0}$ at $30^{\circ} \mathrm{C} .^{41,42}$

$$
\begin{aligned}
& \mathrm{Cu}+\mathrm{H}_{2} \mathrm{O}_{2}+2 \mathrm{HF} \rightarrow \mathrm{CuF}_{2}+2 \mathrm{H}_{2} \mathrm{O} \quad \Delta \mathrm{G}^{0}=-71.3 \mathrm{~kJ} \\
& \mathrm{~Pb}+\mathrm{H}_{2} \mathrm{O}_{2}+2 \mathrm{HF} \rightarrow \mathrm{PbF}_{2} \downarrow+2 \mathrm{H}_{2} \mathrm{O} \quad \Delta \mathrm{G}^{0}=-90.1 \mathrm{~kJ} \\
& \mathrm{Sn}+2 \mathrm{H}_{2} \mathrm{O}_{2}+6 \mathrm{HF} \rightarrow\left[\mathrm{SnF}_{6}\right]^{2-}+4 \mathrm{H}_{2} \mathrm{O}+2 \mathrm{H}^{+} \\
& \Delta \mathrm{G}^{0}=-168.4 \mathrm{~kJ} \\
& \mathrm{SiO}_{2}+6 \mathrm{HF} \rightarrow\left[\mathrm{SiF}_{6}\right]^{2-}+2 \mathrm{H}^{+}+2 \mathrm{H}_{2} \mathrm{O} \quad \Delta \mathrm{G}^{0}=-43.2 \mathrm{~kJ} \\
& 2 \mathrm{X}+3 \mathrm{H}_{2} \mathrm{O}_{2}+12 \mathrm{HF} \rightarrow 2\left[\mathrm{XF}_{6}\right]^{3-}+6 \mathrm{H}_{2} \mathrm{O}+6 \mathrm{H}^{+}(\mathrm{X}=\mathrm{Al}, \mathrm{Fe}) \\
& \Delta \mathrm{G}^{0} \sim-283.1 \mathrm{~kJ} \quad(5 \\
& \mathrm{Cu}+\mathrm{ClO}^{-}+3 \mathrm{Cl}^{-}+2 \mathrm{HF} \rightarrow\left[\mathrm{CuCl}_{4}\right]^{2-}+\mathrm{H}_{2} \mathrm{O}+2 \mathrm{~F}^{-} \\
& \Delta \mathrm{G}^{0}=-61.3 \mathrm{~kJ} \\
& \mathrm{~Pb}+\mathrm{ClO}^{-}+3 \mathrm{Cl}^{-}+2 \mathrm{HF} \rightarrow\left[\mathrm{PbCl}_{4}\right]^{2-}+\mathrm{H}_{2} \mathrm{O}+2 \mathrm{~F}^{-} \\
& \Delta \mathrm{G}^{0}=-85.2 \mathrm{~kJ} \\
& \mathrm{Sn}+2 \mathrm{ClO}^{-}+6 \mathrm{HF} \rightarrow\left[\mathrm{SnF}_{6}\right]^{2-}+2 \mathrm{H}_{2} \mathrm{O}+2 \mathrm{H}^{+}+2 \mathrm{Cl}^{-} \\
& \Delta \mathrm{G}^{0}=-158.1 \mathrm{~kJ} \\
& 2 \mathrm{Au}+3 \mathrm{ClO}^{-}+5 \mathrm{Cl}^{-}+6 \mathrm{HF} \rightarrow 2\left[\mathrm{AuCl}_{4}\right]^{-}+3 \mathrm{H}_{2} \mathrm{O}+6 \mathrm{~F}^{-} \\
& \Delta \mathrm{G}^{0}=-201.5 \mathrm{~kJ} \\
& \mathrm{Pd}+\mathrm{ClO}^{-}+3 \mathrm{Cl}^{-}+2 \mathrm{HF} \rightarrow\left[\mathrm{PdCl}_{4}\right]^{2-}+\mathrm{H}_{2} \mathrm{O}+2 \mathrm{~F}^{-} \\
& \Delta \mathrm{G}^{0}=-73.7 \mathrm{~kJ} \\
& 2 \mathrm{Ag}+\mathrm{ClO}^{-}+\mathrm{Cl}^{-}+2 \mathrm{HF} \rightarrow 2 \mathrm{AgCl} \downarrow+\mathrm{H}_{2} \mathrm{O}+2 \mathrm{~F}^{-} \\
& \Delta \mathrm{G}^{0}=-73.4 \mathrm{~kJ}
\end{aligned}
$$

All experiments were performed to verify the reproducibility of them. It was found that the error percentage was on the order of $\pm 4 \%$. 


\section{Recovery of lead and noble metals}

The strategy adopted to process the solid after leaching PCBs with $\mathrm{HF}+\mathrm{H}_{2} \mathrm{O}_{2}$ mixtures is based on the solubility of lead(II) fluoride in water and the reactivity of noble metals and alkali-earth fluorides in the presence of nitric acid $\left(\mathrm{HNO}_{3}\right)$ :

- Water: based on the solubility data for lead(II) fluoride $\left(\mathrm{K}_{\mathrm{sp}}=2.7 \times 10^{-8}\right)$ it is expected to dissolve it in hot water. ${ }^{43}$ Alkali-earth fluorides do not dissolve significantly in this solvent whatever the temperature. Distilled water was added to the gray solid $\left(25 \mathrm{~mL} \mathrm{~g}^{-1}\right)$ under heating at $\sim 90^{\circ} \mathrm{C}(200$ rotations per minute $)$. After $15 \mathrm{~min}$ the hot aqueous solution was filtered as quickly as possible through a filter paper under vacuum into a plastic vessel. The solid was washed with $0.1 \mathrm{~mol} \mathrm{~L}^{-1} \mathrm{HF}\left(2 \mathrm{~mL} \mathrm{~g}^{-1}\right)$. The washings were added to the filtrate and the system was cooled down to $\sim 0{ }^{\circ} \mathrm{C}$. This procedure accelerated crystallization of a white solid $\left(\mathrm{PbF}_{2}\right)$ due to the common ion effect and the lower solubility of this salt in cold water. ${ }^{43} \mathrm{Lead}(\mathrm{II})$ fluoride was isolated by filtration.

- 2 mol L-1 $\mathrm{HNO}_{3}$ : it dissolves the base metals via oxidation and the lead and alkali-earth fluorides ${ }^{44}$ by conversion of fluoride to nonionized HF $\left(K_{\mathrm{a}}=7.2 \times 10^{-4}\right)$. The noble metals are not affected but copper may be dissolved: ${ }^{45,46}$

$\mathrm{XF}_{2}+2 \mathrm{H}_{3} \mathrm{O}^{+} \rightarrow \mathrm{X}^{2+}+2 \mathrm{HF}+2 \mathrm{H}_{2} \mathrm{O}$

$$
(\mathrm{X}=\mathrm{Pb}, \mathrm{Mg}, \mathrm{Ca}, \mathrm{Sr}, \mathrm{Ba})
$$

$K_{\text {eq }}=K_{\text {sp }} \mathrm{XF}_{2} /\left(K_{\mathrm{a}} \mathrm{HF}\right)^{2}$ ranges from $8 \times 10^{-5}\left(\mathrm{CaF}_{2}\right)$ to $0.4\left(\mathrm{BaF}_{2}\right)$

$3 \mathrm{Cu}+8 \mathrm{HNO}_{3} \rightarrow 3 \mathrm{Cu}^{2+}+2 \mathrm{NO}+4 \mathrm{H}_{2} \mathrm{O}+6 \mathrm{NO}_{3}$

$$
\Delta \mathrm{E}^{0}=+0.620 \mathrm{~V}
$$

- $8 \mathrm{~mol} \mathrm{~L}^{-1} \mathrm{HNO}_{3}$ : it dissolves silver metal: $:^{35,45,46}$

$$
3 \mathrm{Ag}+4 \mathrm{HNO}_{3} \rightarrow 3 \mathrm{Ag}^{+}+\mathrm{NO}+2 \mathrm{H}_{2} \mathrm{O}+3 \mathrm{NO}_{3}^{-}
$$$$
\Delta \mathrm{E}^{0}=+0.157 \mathrm{~V}
$$

- $16 \mathrm{~mol} \mathrm{~L}^{-1} \mathrm{HNO}_{3}$ : it dissolves palladium metal. The solution acquires a brownish color. ${ }^{35,45,46}$ Gold is the final insoluble matter.

$$
\begin{array}{r}
3 \mathrm{Pd}+8 \mathrm{HNO}_{3} \rightarrow 3 \mathrm{Pd}^{2+}+2 \mathrm{NO}+4 \mathrm{H}_{2} \mathrm{O}+6 \mathrm{NO}_{3}{ }^{-} \\
\Delta \mathrm{E}^{0}=+0.042 \mathrm{~V}
\end{array}
$$

The solid/liquid ratio was fixed at $5 \mathrm{~mL} \mathrm{HNO}_{3 \mathrm{aq}} \mathrm{g}^{-1}$ solid. Experiments were run for $1 \mathrm{~h}$ at $\sim 50-60{ }^{\circ} \mathrm{C}$ under stirring $(200$ rotations per minute). After each step the remaining insoluble matter was isolated by centrifugation, washed with water $\left(2 \mathrm{~mL} \mathrm{~g}^{-1}\right)$ and again centrifuged.

The solid obtained after leaching $\mathrm{PCBs}$ with $\mathrm{HF}+\mathrm{NaClO}$ mixtures was treated with $6 \mathrm{~mol} \mathrm{~L}^{-1} \mathrm{NH}_{3 \text { aq. }}\left(2 \mathrm{~mL} \mathrm{~g}^{-1}\right)$ at $\sim 25^{\circ} \mathrm{C}$ under stirring (200 rotations per minute) for $15 \mathrm{~min}$. Silver chloride can be easily separated from the other compounds via a complexation reaction: ${ }^{35}$

$\mathrm{AgCl}+2 \mathrm{NH}_{3} \rightleftarrows\left[\mathrm{Ag}\left(\mathrm{NH}_{3}\right)_{2}\right]^{+}+\mathrm{Cl}^{-} \quad \mathrm{K}_{\text {form }}=1.7 \times 10^{7}$

The insoluble matter was isolated by centrifugation, washed with $0.01 \mathrm{~mol} \mathrm{~L}^{-1} \mathrm{NH}_{3 \text { aq. }}\left(2 \mathrm{~mL} \mathrm{~g}^{-1}\right)$, and again centrifuged. Silver chloride was recovered by slow evaporation of the aqueous ammoniacal solution.

A classical method was used to extract soluble gold from the leachate after leaching with $\mathrm{HF}+\mathrm{NaClO}$. Pure methyl isobutyl ketone (methyl-4-pentan-2-one, MIBK) was used. ${ }^{47-49}$ It is suitable to separate small amounts of gold from other elements in complex matrices. The experiments were performed at $25^{\circ} \mathrm{C}$. The aqueous/ organic $(\mathrm{A} / \mathrm{O})$ phase ratio was $1 \mathrm{vol} / \mathrm{vol}$. $\mathrm{pH}$ of the leachate was not changed. The system was shaken for $10 \mathrm{~min}$. Phase separation was achieved in $\sim 10 \mathrm{~min}$. The experiments were carried out in triplicate. The error percentage was in the order of $\pm 5 \%$.

\section{Analytical methods}

The greenish-milky solid recovered after treating PCB with $6 \mathrm{~mol} \mathrm{~L}^{-1} \mathrm{NaOH}$ was analyzed by FTIR (Nicolet 6700 FTIR, 2 wt. $\%$ in $\mathrm{KBr}$ pellets). Metal ion concentrations in the solutions were determined by atomic absorption spectrometry (Perkin Elmer AAS 3300). $\mathrm{pH}$ measurements of aqueous solutions were conducted using a combination of a glass electrode and $\mathrm{Ag} / \mathrm{AgCl}$ reference electrode (Orion 2AI3-JG). Free fluoride was determined by potentiometry using an ion selective electrode (Orion 9409) attached to a $\mathrm{pH} /$ ion meter (Orion 720A). A total ionic strength adjustment buffer (TISAB) consisting of an acetic acid - sodium acetate buffer and $\mathrm{NaCl}$ was used. Total fluoride was also determined by potentiometry after addition of TISAB III (Thermo Scientific) containing CDTA (trans-1,2-cyclohexylenedinitrilotetraacetic acid), which releases fluoride ions from metal-F complexes. ${ }^{50}$

The solids obtained during processing of PCBs were weighed in an analytical balance (Scientech SA 120) and analyzed by energy dispersive X-ray fluorescence (XRF, Shimadzu model XRF 800HS). Calibration curves $\left(0.1-1000 \mathrm{mg} \mathrm{kg}^{-1}\right)$ of the metals found were employed for quantitative analyses. Crystalline phases in the solid samples were identified by X-ray powder diffraction (XRD, Shimadzu model XRD 6000) by continuous scanning method at $20 \mathrm{~mA}$ and $40 \mathrm{kV}$, using $\mathrm{Cu} \mathrm{K} \alpha$ as the radiation source.

\section{RESULTS AND DISCUSSION}

\section{Treatment of PCBs with $6 \mathrm{~mol} \mathrm{~L}^{-1} \mathrm{NaOH}$}

The effect of time on removal of the soldering mask is shown in Figure 1. After $1 \mathrm{~h}$ the mass loss was constant $(\sim 2.5 \mathrm{wt} . \%)$. The treated PCB lost its original bright (Figure 2). No component attached to the PCBs was released during this treatment. Apart from sodium ions, XRF data did not detect any other metal present in the alkaline solution.

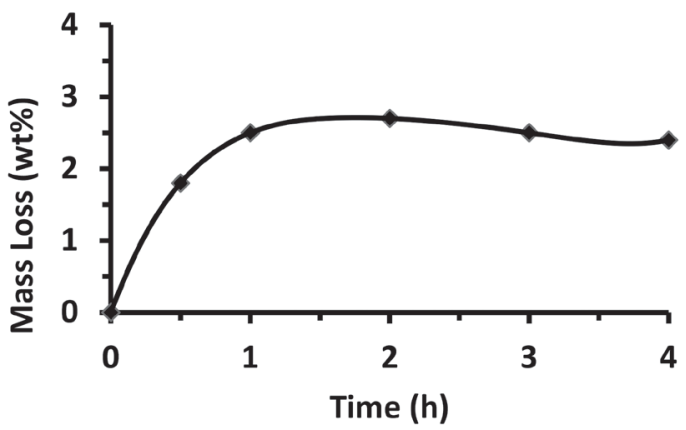

Figure 1. Mass loss of PCBs after treatment with $6 \mathrm{~mol} \mathrm{~L}^{-1} \mathrm{NaOH}$ at $50^{\circ} \mathrm{C}$

The inorganic elements present in the greenish solid (Table 1) come mainly from the laminate. ${ }^{51,52}$ Of particular interest is the presence of bromine. It comes from the flame retardants added to the PCBs. ${ }^{52,53}$ The FTIR spectrum of this solid (Figure 3) is rather complex but presents typical bands of organics functional groups: $\mathrm{O}-\mathrm{H}, \mathrm{N}-\mathrm{H}$, aliphatic chains, carbonyl compounds, $\mathrm{C}=\mathrm{C}$ and $\mathrm{C}-\mathrm{O}$ bonds and probably $\mathrm{C}-\mathrm{Br}\left(597-719 \mathrm{~cm}^{-1}\right) .^{54}$

After burning the greenish solid, the ash corresponds to only $\sim 4$ wt.\% of the initial mass ( 0.1 wt.\% of the original PCB). Except 


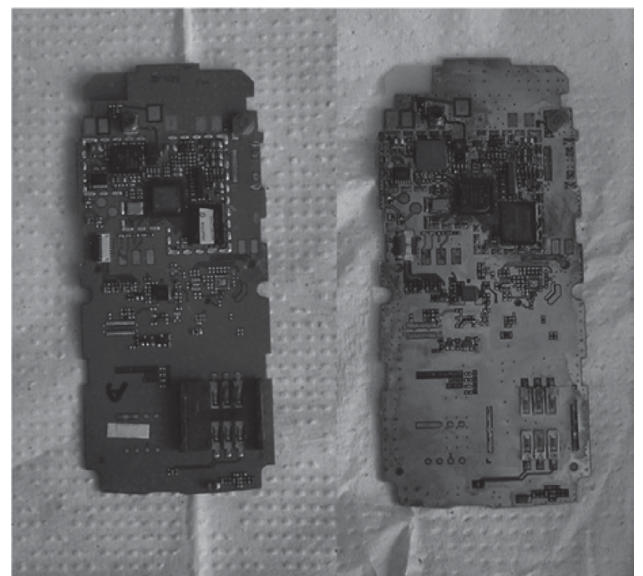

Figure 2. Aspect of the $P C B$ before (left) and after (right) treatment with $6 \mathrm{~mol} \mathrm{~L} \mathrm{~L}^{-1} \mathrm{NaOH}$ at $50^{\circ} \mathrm{C}$ for $1 \mathrm{~h}$

Table 1. XRF data of the greenish solid before calcining

\begin{tabular}{cccc}
\hline Element & wt.\% & Element & wt.\% \\
\hline $\mathrm{Si}$ & 56.1 & $\mathrm{Fe}$ & 1.5 \\
$\mathrm{Ba}$ & 22.5 & $\mathrm{Mg}$ & 1.0 \\
$\mathrm{Br}$ & 15.8 & $\mathrm{Ca}$ & 0.9 \\
$\mathrm{Al}$ & 2.2 & $\mathrm{Sr}, \mathrm{Pb}, \mathrm{Sn}, \mathrm{Ni}, \mathrm{Zn}$ & $<0.1$ \\
\hline
\end{tabular}

for bromine, all elements listed in Table 1 were found in this residue. The greenish solid is essentially organic matter.

\section{Leaching of pretreated PCBs}

\section{General aspects}

The raise of temperature during leaching with $\mathrm{HF}+\mathrm{H}_{2} \mathrm{O}_{2}$ mixtures is explained by the decomposition of the oxidant, which is catalyzed by various transition metals (such as silver, gold and platinum), their oxides and aqueous ions (such as $\mathrm{Cu}^{2+}, \mathrm{Ni}^{2+}, \mathrm{Co}^{2+}$ etc.). ${ }^{41,55,56}$
$2 \mathrm{H}_{2} \mathrm{O}_{2} \rightleftarrows 2 \mathrm{H}_{2} \mathrm{O}+\mathrm{O}_{2} \quad \Delta \mathrm{G}^{0}=-119.6 \mathrm{~kJ}$

The leachate presented a blue color, typical of $\left[\mathrm{Cu}\left(\mathrm{H}_{2} \mathrm{O}\right)_{6}\right]^{2+}$ ions. The components attached to the PCBs were released as long as the solder was dissolved by the leachant. The leachates from $\mathrm{HF}+\mathrm{NaClO}$ mixtures are green in color due to a mixture of $\left[\mathrm{Cu}\left(\mathrm{H}_{2} \mathrm{O}\right)_{6}\right]^{2+}$ and $\left[\mathrm{CuCl}_{4}\right]^{2-}$ ions..$^{35,55}$

\section{Effect of time}

From data on Table 2, the masses of the epoxy resin (laminate), the components attached to the PCB and the fine solid (Figure 4) are constant after leaching for $\sim 1 \mathrm{~h}$ irrespective of the leachant. The laminate is light brown in color and the most important solid waste generated ( $40 \mathrm{wt} . \%$ of the mass of the processed PCB), followed by the attached components ( 12 wt.\%) and the fine solid (1.5-3.0 wt.\%).

Table 2. Average masses of the solids recovered after leaching treated PCBs with $10 \mathrm{~mol} \mathrm{~L}^{-1} \mathrm{HF}+5 \mathrm{~mol} \mathrm{~L}^{-1} \mathrm{H}_{2} \mathrm{O}_{2}$ or $10 \mathrm{~mol} \mathrm{~L}^{-1} \mathrm{HF}+0.4 \mathrm{~mol} \mathrm{~L}^{-1} \mathrm{NaClO}$

\begin{tabular}{lcccc}
\hline \multirow{2}{*}{ Time (h) } & Leachant & $\begin{array}{c}\text { PCB } \\
\text { laminate }\end{array}$ & $\begin{array}{c}\text { PCB } \\
\text { components }\end{array}$ & $\begin{array}{c}\text { Fine } \\
\text { solid** }\end{array}$ \\
\hline 0.5 & $\mathrm{HF}+\mathrm{H}_{2} \mathrm{O}_{2}$ & 520 & 76 & 37.5 \\
1 & $\mathrm{HF}+\mathrm{H}_{2} \mathrm{O}_{2}$ & 406 & 122 & 27.9 \\
2 & $\mathrm{HF}+\mathrm{H}_{2} \mathrm{O}_{2}$ & 399 & 122 & 27.9 \\
3 & $\mathrm{HF}+\mathrm{H}_{2} \mathrm{O}_{2}$ & 404 & 119 & 29.6 \\
\hline 0.5 & $\left.\mathrm{HF}+\mathrm{NaClO}^{-1} \mathrm{PCB}\right)$ & 74 & 23.8 \\
1 & $\mathrm{HF}+\mathrm{NaClO}_{2}$ & 395 & 116 & 14.3 \\
2 & $\mathrm{HF}+\mathrm{NaClO}$ & 395 & 125 & 14.2 \\
\hline
\end{tabular}

* Leds, capacitors, chips, quartz crystals etc.

Metal ion concentrations in the leachates did not change significantly after $1 \mathrm{~h}$ (Table 3 ). The leachates are very complex in nature, but copper is largely the main element present, followed by silicon. Sodium hypochlorite was a less selective oxidant than

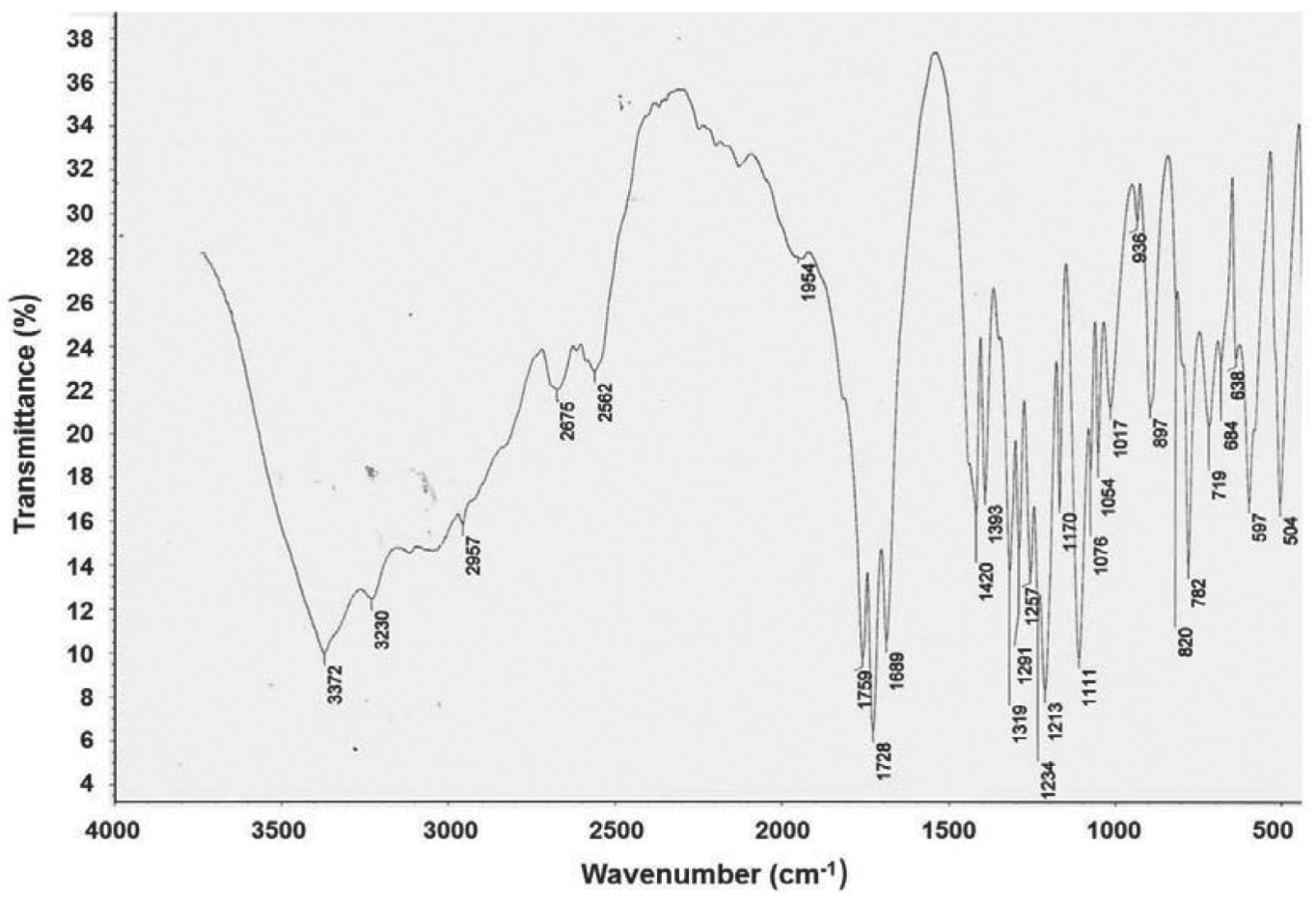

Figure 3. IR spectrum of the greenish solid recovered after treatment of $\mathrm{PCB}$ with $6 \mathrm{~mol} \mathrm{~L}^{-1} \mathrm{NaOH}$ at $50^{\circ} \mathrm{C}$ for $1 \mathrm{~h}$ 
hydrogen peroxide. Besides the leached elements with $\mathrm{HF}+\mathrm{H}_{2} \mathrm{O}_{2}$ mixtures, lead and the noble metals were also oxidized and leached (Table 3), except silver, which precipitated as $\mathrm{AgCl}$.

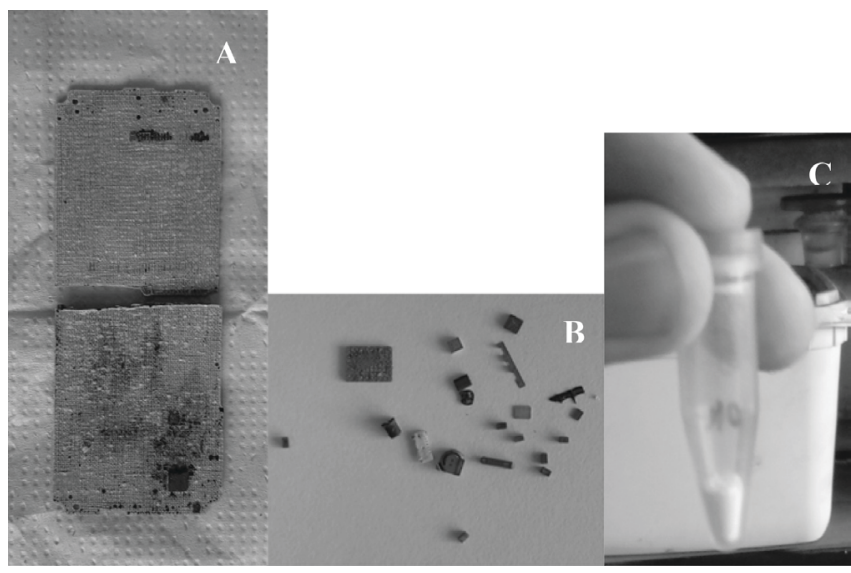

Figure 4. The final solids obtained from PCBs after pretreatment with 6 mol L $\mathrm{L}^{-1}$ $\mathrm{NaOH}$ followed by leaching with $\mathrm{HF}+\mathrm{H}_{2} \mathrm{O}_{2}$ mixtures: (A) the epoxy resin laminate; $(B)$ the components released from the PCBs; $(C)$ the precipitate containing lead, alkali-earth and noble metals

$\mathrm{pH}$ of all leachates was in the range 1.1-1.3 after leaching for $1 \mathrm{~h}$ (or more). It is slightly higher than the $\mathrm{pH}$ of the original leachate (1.0-1.1). Reactions (1) to (11) consume some acidity from the leachate. The remaining acidity is mainly due to excess of HF used for leaching. However, anions such as $\mathrm{SiF}_{6}{ }^{2-}, \mathrm{SnF}_{6}{ }_{6}^{2-}, \mathrm{AlF}_{6}{ }^{3-}$ and $\mathrm{FeF}_{6}{ }^{3-}$ come from strong acids (reactions $3,4,5$ and 8), ${ }^{35,57}$ thus also contributing to the acidity of the leachate.

The aspect and composition of the fine solid (Table 4) depend on the leachant employed. The gray solid $\left(\mathrm{HF}+\mathrm{H}_{2} \mathrm{O}_{2}\right)$ is mainly composed by lead, noble metals and alkali-earth elements
(> 80 wt. \%). Some Al, $\mathrm{Fe}, \mathrm{Si}, \mathrm{Sn}$ and $\mathrm{Cu}$ were also found. The white solid $(\mathrm{HF}+\mathrm{NaClO})$ is mainly composed by silver chloride, alkaliearth elements and lead (> $80 \mathrm{wt} \%)$. In both cases the alkali-earth elements were probably precipitated as fluorides $\left(\mathrm{XF}_{2}, \mathrm{X}=\mathrm{Mg}^{2+}\right.$, $\mathrm{Ca}^{2+}, \mathrm{Sr}^{2+}$ and $\mathrm{Ba}^{2+}$ ), which are insoluble in water and $\mathrm{HF}_{\mathrm{aq}}{ }^{44}$ Both leachants oxidized lead (reactions 2 and 7) but its solubility was strongly dependant on the halide ion present. Lead(II) fluoride readily precipitated because of the high $\mathrm{F}^{-}$concentration in the leachates (common ion effect). It does not form soluble fluorocomplexes. On the other hand, $\mathrm{PbCl}_{2}\left(\mathrm{~K}_{\mathrm{sp}}=1.6 \times 10^{-5}\right)$ is more soluble in water and $\mathrm{Pb}$ (II) is easily complexed by $\mathrm{Cl}^{-}$ions $\left(\mathrm{K}_{\text {form }}\left[\mathrm{PbCl}_{4}\right]^{2-}=2.5 \times 10^{15}\right) .^{34,35}$ Tin was highly leached (>95 wt.\%) by both leachants as very stable $\left[\mathrm{SnF}_{6}\right]^{2-}$ anions are formed $\left(\mathrm{K}_{\text {form }} \sim 10^{25}\right),{ }^{35}$ see reaction 3$)$. The amount of fine solid is lower after experiments with $\mathrm{HF}+\mathrm{NaClO}$ (Table 2), due basically to the solubility of lead in this leachant (Table 3).

\section{Elements distribution}

According to data of Tables 3 and 4, the elements can be divided into three groups: those which ever remained in the insoluble matter (Ag, $\mathrm{Mg}, \mathrm{Ca}, \mathrm{Sr}, \mathrm{Ba}$ ); those which were mainly $(\mathrm{Cu}, \mathrm{Sn}, \mathrm{Si}, \mathrm{Al}$, Fe: $>80$ wt.\%) or even fully ( $\mathrm{Zn}, \mathrm{Cr}, \mathrm{Ni}$ ) leached due to oxidation/ complexation reactions; those whose behavior depended on the oxidant present in the leachant $(\mathrm{Pb}, \mathrm{Au}, \mathrm{Pd})$. Of particular interest is that copper was highly leached (>99.5 wt.\%) after a very short time $(\sim 1 \mathrm{~h})$ and under very mild experimental conditions $\left(T_{\max } 40{ }^{\circ} \mathrm{C}\right)$. High copper leaching yields normally require longer times $(>2 \mathrm{~h}$ ) and higher temperatures $\left(>60{ }^{\circ} \mathrm{C}\right)$ using ground $\mathrm{PCBs}$ in sulfuric, nitric or hydrochloric acid medium. ${ }^{7,31,58-60}$ The recovery of copper and other leached elements as well as the fluoride ions employed for leaching has already been performed. ${ }^{61}$

$\mathrm{HF}+\mathrm{H}_{2} \mathrm{O}_{2}$ mixtures presented a particular feature: all noble metals were concentrated into a very small and less complex mass fraction ( 3.0 wt.\%) of the original PCB, thus meaning a mass concentration factor of $30-35$. This makes their separation

Table 3. Average metal ion concentrations in the leachates

\begin{tabular}{|c|c|c|c|c|c|c|c|c|c|c|c|c|}
\hline \multirow{2}{*}{ Time (h) } & \multirow{2}{*}{ Leachant** } & \multicolumn{11}{|c|}{ Concentration $\left(\mathrm{mg} \mathrm{L}^{-1}\right)$} \\
\hline & & $\mathrm{Cu}$ & $\mathrm{Ni}$ & $\mathrm{Zn}$ & $\mathrm{Cr}$ & $\mathrm{Al}$ & $\mathrm{Fe}$ & $\mathrm{Pb}$ & $\mathrm{Sn}$ & $\mathrm{Si}$ & $\mathrm{Au}$ & $\mathrm{Pd}$ \\
\hline 0.5 & $\mathrm{HF}+\mathrm{H}_{2} \mathrm{O}_{2}$ & 11600 & 970 & 1200 & 30 & 210 & 290 & $<0.1$ & 720 & 1715 & $\mathrm{nd}^{*}$ & nd \\
\hline 1 & $\mathrm{HF}+\mathrm{H}_{2} \mathrm{O}_{2}$ & 12570 & 1320 & 1770 & 45 & 340 & 330 & $<0.1$ & 780 & 1790 & nd & nd \\
\hline 2 & $\mathrm{HF}+\mathrm{H}_{2} \mathrm{O}_{2}$ & 12600 & 1320 & 1800 & 48 & 340 & 340 & $<0.1$ & 790 & 1780 & nd & nd \\
\hline 0.5 & $\mathrm{HF}+\mathrm{NaClO}$ & 11480 & 1000 & 1280 & 37 & 270 & 325 & 490 & 730 & 1660 & 35 & 10 \\
\hline 1 & $\mathrm{HF}+\mathrm{NaClO}$ & 12820 & 1330 & 1730 & 44 & 395 & 355 & 525 & 780 & 1810 & 55 & 17 \\
\hline 2 & $\mathrm{HF}+\mathrm{NaClO}$ & 12870 & 1320 & 1700 & 46 & 375 & 350 & 515 & 785 & 1810 & 55 & 16 \\
\hline
\end{tabular}

*nd - not detected;**10 mol L-1 $\mathrm{HF}+5 \mathrm{~mol} \mathrm{~L}-1 \mathrm{H}_{2} \mathrm{O}_{2}$ or $10 \mathrm{~mol} \mathrm{~L}^{-1} \mathrm{HF}+0.4 \mathrm{~mol} \mathrm{~L}^{-1} \mathrm{NaClO}$.

Table 4. Mass percentage of elements in the gray or white fine solid

\begin{tabular}{|c|c|c|c|c|c|c|c|c|c|c|c|c|}
\hline \multirow[b]{2}{*}{ Time (h) } & \multirow[b]{2}{*}{ Leachant** } & \multicolumn{11}{|c|}{ Amount (wt.\%) } \\
\hline & & $\mathrm{Cu}$ & $\mathrm{Ag}$ & $\mathrm{Au}$ & $\mathrm{Pd}$ & $\mathrm{Al}$ & $\mathrm{Fe}$ & $\mathrm{Pb}$ & $\mathrm{Sn}$ & $\mathrm{Si}$ & $\begin{array}{c}\mathrm{Mg} / \mathrm{Ca} / \\
\mathrm{Sr} / \mathrm{Ba}\end{array}$ & $\mathrm{Cl}$ \\
\hline 0.5 & $\mathrm{HF}+\mathrm{H}_{2} \mathrm{O}_{2}$ & 18.6 & 8.8 & 3.4 & 1.0 & 8.0 & 3.8 & 37.0 & 5.1 & 2.7 & 11.6 & nd* \\
\hline 1 & $\mathrm{HF}+\mathrm{H}_{2} \mathrm{O}_{2}$ & 5.4 & 11.9 & 4.5 & 1.4 & 2.9 & 4.4 & 48.7 & 5.0 & 0.3 & 15.5 & nd \\
\hline 2 & $\mathrm{HF}+\mathrm{H}_{2} \mathrm{O}_{2}$ & 5.1 & 11.7 & 4.7 & 1.5 & 2.7 & 4.7 & 48.8 & 4.9 & 0.3 & 15.6 & nd \\
\hline 0.5 & $\mathrm{HF}+\mathrm{NaClO}$ & 23.0 & 13.8 & nd & nd & 10.5 & 5.4 & 11.8 & 6.0 & 7.1 & 18.0 & 4.4 \\
\hline 1 & $\mathrm{HF}+\mathrm{NaClO}$ & 6.2 & 23.1 & nd & nd & 5.6 & 5.8 & 18.4 & 2.8 & 0.7 & 29.8 & 7.6 \\
\hline 2 & $\mathrm{HF}+\mathrm{NaClO}$ & 5.7 & 23.2 & nd & nd & 5.6 & 5.9 & 18.5 & 2.6 & 0.7 & 30.2 & 7.6 \\
\hline
\end{tabular}

*nd - not detected; **10 mol L-1 $\mathrm{HF}+5 \mathrm{~mol} \mathrm{~L}-1 \mathrm{H}_{2} \mathrm{O}_{2}$ or $10 \mathrm{~mol} \mathrm{~L}^{-1} \mathrm{HF}+0.4 \mathrm{~mol} \mathrm{~L}^{-1} \mathrm{NaClO}$. 
by conventional methods easier. An efficient recovery of precious metals of PCBs from WEEE is essential to offset demand for primary resources. ${ }^{17} \mathrm{HF}+\mathrm{NaClO}$ mixtures were less performant in this aspect because gold and palladium were brought into a complex leachate as minor components, making their recovery more difficult.

After leaching for $1 \mathrm{~h}$ the laminate did not present any visible vestige of copper. Other metals, silicon and bromine were not detected by XRF. Thus, based on data of Tables 3 and 4 and the masses of the processed PCBs $(15.11 \pm 0.35 \mathrm{~g})$, the average copper and precious metals content in these samples are: copper, $299 \mathrm{~g} \mathrm{~kg}^{-1}$; silver, $3.25 \mathrm{~g} \mathrm{~kg}^{-1}$; gold, $1.28 \mathrm{~g} \mathrm{~kg}^{-1}$; palladium, $380 \mathrm{mg} \mathrm{kg}^{-1}$. These results are in the range reported in the literature for PCBs from cell phones. ${ }^{6,7,17,32,58-60}$

\section{Influence of reactants concentration}

Copper was chosen to monitor the leaching processes. The presence of an oxidant is essential to perform leaching as $\mathrm{HF}$ alone is practically not reactive towards treated PCBs (Figure 5). Concentrations above 3 mol L-1 $\mathrm{H}_{2} \mathrm{O}_{2}$ did not change leaching yield. An excess of $\mathrm{H}_{2} \mathrm{O}_{2}$ leads to $\mathrm{HF}$ losses from the leachant. ${ }^{62,63}$ Taking into account the metals content in the leachates (Table 3), this concentration is in large excess as expected from the oxidative leaching reactions ( 1 to 3 and 5). This oxidant plays a double role during leaching. It oxidizes $\mathrm{Cu}, \mathrm{Pb}, \mathrm{Sn}$ etc. at the same time it is partially decomposed, thus heating the reaction mixture. Concentrations above $0.3 \mathrm{~mol} \mathrm{~L}^{-1} \mathrm{NaClO}$ served no advantage. Taking into account copper concentration in the leachates (Table 3 ) and its oxidation reaction (reaction 6 ), this concentration is about $30 \%$ higher than the stoichiometric amount required for such.

Figure 6 shows that, under our experimental conditions, HF concentration may be reduced to $\sim 3.5 \mathrm{~mol} \mathrm{~L}^{-1}$ without changing significantly the time and leaching yield. A lower HF concentration allows a safer handling of the leachants and leachates. Below $3.5 \mathrm{~mol} \mathrm{~L}^{-1} \mathrm{HF}$, traces of copper and blue-green spots on the surface of the laminate were still observable after leaching for $1 \mathrm{~h}$.

\section{Recovery of lead}

The diffractogram (Figure 7) of the white solid corresponds to $\alpha-\mathrm{PbF}_{2}{ }^{64}$ It contains $99.6 \mathrm{wt} . \%$ of lead present in the processed PCBs. Barium (0.1 wt. \%) and calcium (0.1 wt. \%) are the only foreign elements found according to XRF data.

\section{Recovery of noble metals}

Gray solid ( $\mathrm{HF}+\mathrm{H}_{2} \mathrm{O}_{2}$ mixtures)

The sequential treatment of the fine gray solid with nitric acid proved to be successful (Table 5). The first step "cleaned" the solid, removing copper, alkali-earth elements and almost all base metals. The $\mathrm{Ag}(\mathrm{I})$ acidic solution can be evaporated (in darkness) to recover silver nitrate..$^{55} \mathrm{Pd}(\mathrm{II})$ can be isolated by solvent-extraction

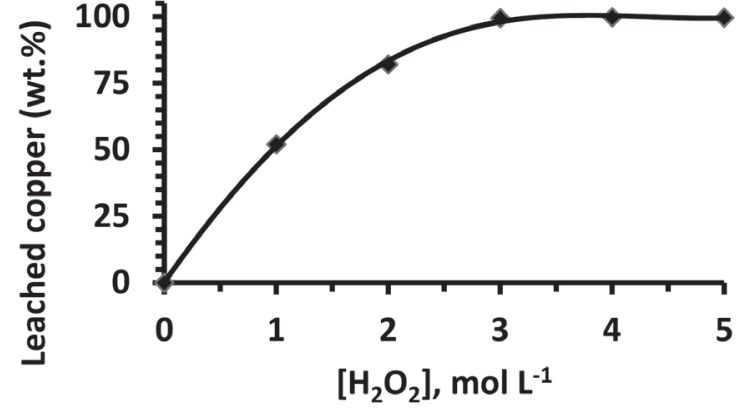

Figure 5. Effect of $\mathrm{H}_{2} \mathrm{O}_{2}$ concentration on leaching. $[\mathrm{HF}]=10 \mathrm{~mol} \mathrm{~L}^{-1}, t=1 \mathrm{~h}$

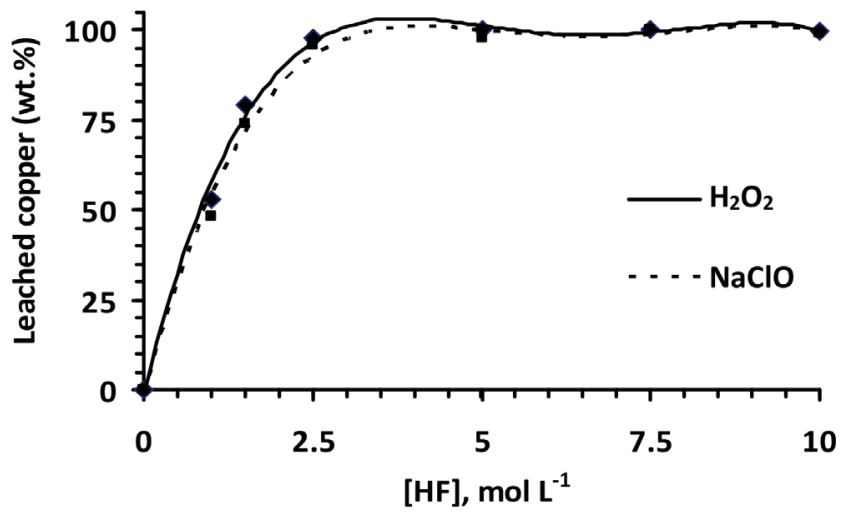

Figure 6. Effect of $\mathrm{HF}$ concentration on leaching. $\left[\mathrm{H}_{2} \mathrm{O}_{2}\right]=5 \mathrm{~mol} \mathrm{~L}{ }^{-1}$; $[\mathrm{NaClO}]=0.4 \mathrm{~mol} \mathrm{~L}^{-1} ; t=1 \mathrm{~h}$

techniques. ${ }^{65,66}$ Gold was recovered as very thin yellow blades. XRF data show these blades contain minor amounts of silicon $(<0.1 \mathrm{wt} . \%)$.

\section{White solid and leachate ( $\mathrm{HF}+\mathrm{NaClO}$ mixtures)}

As expected, the purity of silver chloride recovered after evaporation of its ammoniacal solution surpasses 99.9 wt.\%, with minor amounts of copper $(<0.1 \mathrm{wt} . \%)$. This solid is white.

The effectiveness of liquid-liquid extraction of gold using pure MIBK is shown in Table 6. More than 99.9 wt.\% of Au(III) was extracted in one stage. Traces of Fe(III) and Sn(IV) were also extracted. They are normally interferents in gold extraction using MIBK, ${ }^{48,67,68}$ but their low extraction may be explained by the formation of very stable fluorocomplexes $\left(\mathrm{FeF}_{6}{ }^{3-}, \mathrm{SnF}_{6}{ }^{2-} \text { - reactions (3) and (5)) }\right)^{35,55}$ which masks solvent-extraction of these elements by MIBK.

\section{Mass balance for fluoride}

Any WEEE recycling process must intent the pollution reduction of soil and groundwater caused by leached percolation and compliance with the existing laws. Hydrofluoric acid is recognized as a hazardous

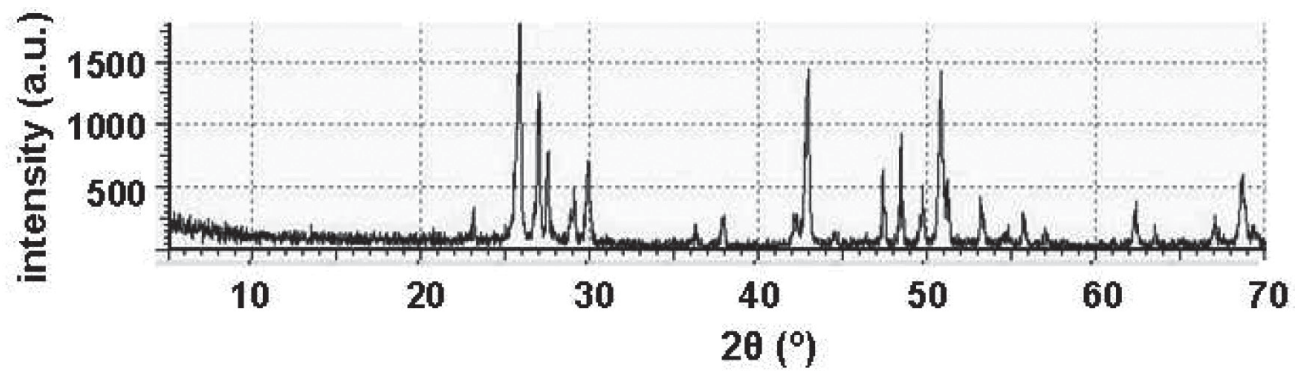

Figure 7. Diffractogram of the white solid isolated after adding $\mathrm{H}_{2} \mathrm{O}\left(\sim 90{ }^{\circ} \mathrm{C}\right)$ to the gray solid followed by filtration, washing of the insoluble matter with $0.1 \mathrm{~mol} \mathrm{~L} \mathrm{~L}^{-1} \mathrm{HF}$ and cooling the filtrate + washings to $\sim{ }^{\circ} \mathrm{C}$. The peaks represent $\alpha-\mathrm{PbF}_{2}$ 
Table 5. Mass percentage of elements (wt. \%) in the fine solid ( $\mathrm{HF}+\mathrm{H}_{2} \mathrm{O}_{2}$ experiments) after sequential treatment with aqueous $\mathrm{HNO}_{3}$

\begin{tabular}{lccccccccccc}
\hline $\begin{array}{l}\mathrm{HNO}_{3} \\
\left(\mathrm{~mol} \mathrm{~L}^{-1}\right)\end{array}$ & Color of the solid & $\mathrm{Cu}$ & $\mathrm{Ag}$ & $\mathrm{Au}$ & $\mathrm{Pd}$ & $\mathrm{Al}$ & $\mathrm{Fe}$ & $\mathrm{Pb}$ & $\mathrm{Sn}$ & $\mathrm{Si}$ & $\begin{array}{c}\mathrm{Mg}+\mathrm{Ca}+ \\
\mathrm{Sr}+\mathrm{Ba}\end{array}$ \\
\hline 0 & Gray & 5.4 & 11.9 & 4.5 & 1.4 & 2.9 & 4.4 & 48.7 & 5.0 & 0.3 & 15.5 \\
2 & Silvery & - & 66.8 & 25.1 & 7.8 & - & - & 0.1 & 0.1 & $<0.1$ & 0.1 \\
8 & Yellowish & - & $<0.1$ & 76.2 & 23.7 & - & - & - & - & 0.1 & - \\
16 & Yellow & - & $<0.1$ & 99.9 & - & - & - & - & - & $<0.1$ & - \\
\hline
\end{tabular}

Table 6. Elements extracted by pure MIBK from $\mathrm{HF}+\mathrm{NaClO}$ leachates $\left(25^{\circ} \mathrm{C}, \mathrm{A} / \mathrm{O}\right.$ phase ratio 1 vol./vol., one stage $)$

\begin{tabular}{lcccccccc}
\hline Element & $\mathrm{Cu}$ & $\mathrm{Au}$ & $\mathrm{Pd}$ & $\mathrm{Al}$ & $\mathrm{Fe}$ & $\mathrm{Pb}$ & $\mathrm{Sn}$ & $\mathrm{Si}$ \\
\hline wt.\% extracted & $<0.1$ & $>99.9$ & n.d. & n.d. & 0.4 & n.d. & 0.2 & n.d. \\
\hline
\end{tabular}

n.d. - not detected.

chemical. Any process in which it is used requires monitoring of fluoride losses (final effluents, release to the gaseous phase).

The starting point is the $\mathrm{HF}+\mathrm{H}_{2} \mathrm{O}_{2}$ mixture, which contains all fluoride of the leachant. Fluoride ion is present (i) in the insoluble matter after leaching PCBs (alkali-earth fluorides and $\mathrm{PbF}_{2}$ ); (ii) in the leachate either as free fluoride or fluorocomplexes (Al, Sn, Fe, $\mathrm{Si}$ ). Two potential sources of loss of fluoride ions were identified: (i) as $\mathrm{HF}$ in the gas phase due to heat and $\mathrm{O}_{2}$ released during leaching of PCBs; (ii) during leachate handling.

The fluoride mass balance was performed using $5 \mathrm{~mol} \mathrm{~L}^{-1} \mathrm{HF}+$ 5 mol L-1 $\mathrm{H}_{2} \mathrm{O}_{2}$ leachant. Data are presented in Table 7. Over 99 wt. $\%$ of fluoride ions are present in the leachate, mainly ( 90 wt.\%) as free fluoride. It comes from the excess of HF of the leachant. The remaining fluoride is present in the form of fluorocomplexes (Al, $\mathrm{Fe}, \mathrm{Sn}, \mathrm{Si})$. The insoluble matter contains less than $0.2 \mathrm{wt} . \%$. On the other hand losses of HF were very low ( 0.4 wt.\%). This result can be attributed to: (i) the low leaching temperature $\left(40{ }^{\circ} \mathrm{C}\right.$ maximum); (ii) the smooth $\mathrm{H}_{2} \mathrm{O}_{2}$ decomposition; (iii) the opening of the vessel after cooling down to $25^{\circ} \mathrm{C}$.

Table 7. Fluoride distribution in the leachates and insoluble matter (base: $1 \mathrm{~L}$ leachate)

\begin{tabular}{|c|c|c|}
\hline Leachant/Fraction & $\begin{array}{c}\text { Mass of } F^{-} \mathrm{L}^{-1} \\
\text { leachate }(\mathrm{g})\end{array}$ & $\begin{array}{l}\text { Relative amount } \\
\text { (wt. } \% \text { ) }\end{array}$ \\
\hline $\mathrm{HF} 5 \mathrm{~mol} \mathrm{~L}^{-1}+\mathrm{H}_{2} \mathrm{O}_{2} 5 \mathrm{~mol} \mathrm{~L}^{-1}$ & 95.0 & $100 \%$ \\
\hline \multicolumn{3}{|l|}{ Insoluble matter } \\
\hline $\mathrm{XF}_{2}\left(\mathrm{X}=\mathrm{Mg}^{2+}, \mathrm{Ca}^{2+}, \mathrm{Sr}^{2+}, \mathrm{Ba}^{2+}\right)^{*}$ & $\sim 0.08$ & 0.08 \\
\hline $\mathrm{PbF}_{2}^{*}$ & $\sim 0.07$ & 0.07 \\
\hline \multicolumn{3}{|l|}{ Leachate } \\
\hline Free fluoride & 84.68 & 89.14 \\
\hline Complexed fluoride & 9.78 & 10.29 \\
\hline Total fluoride & 94.46 & 99.43 \\
\hline Losses & 0.39 & 0.41 \\
\hline
\end{tabular}

*Precipitated together with noble metals as insoluble matter in the leachate.

\section{CONCLUSIONS}

Processing of non-ground PCBs from cell phones was fast $(\sim 1$ h) under mild conditions $\left(\mathrm{T}_{\max } 40^{\circ} \mathrm{C}\right)$ using $\mathrm{HF}+$ oxidant mixtures provided the soldering mask is previously removed by treatment with $\mathrm{NaOH}_{\mathrm{aq}}$. This step did not attack significantly the metals present (even those of the solder), removed bromine from the $\mathrm{PCB}$, and plays the same role of crushing or grinding the $\mathrm{PCB}$ reported in the literature to expose metals to the action of leachants and hence to facilitate their efficient leaching.

Three solids were recovered after leaching: i) the epoxy resin, the attached components released during leaching and a fine gray or white solid. Copper, silicon and other base metals (Cr, Ni, Zn, Fe, Al, $\mathrm{Sn})$ were almost completely leached by both leachants, whereas the alkali-earth elements remained in the fine solid. The main difference between the two leachants was the behavior of lead and noble metals. Lead was oxidized and precipitated using $\mathrm{HF}+\mathrm{H}_{2} \mathrm{O}_{2}$ mixtures, but the noble metals were not oxidized. Lead, palladium and gold were oxidized and leached by $\mathrm{HF}+\mathrm{NaClO}$ mixtures, whereas silver precipitated as chloride. Leached gold was extracted using methyl isobutyl ketone. Silver chloride was separated from the white solid using aqueous ammonia. Processing of the gray solid by hot water followed by oxidative leaching using nitric acid ( 2 to $16 \mathrm{~mol} \mathrm{~L}^{-1}$ ) allowed recovery of lead, silver, palladium and gold in this order.

$\mathrm{HF}+\mathrm{H}_{2} \mathrm{O}_{2}$ mixtures were able to separate the elements present in PCBs from cell phones into four groups: those that are precipitated by fluoride ions $(\mathrm{Mg}, \mathrm{Ca}, \mathrm{Sr}, \mathrm{Ba}, \mathrm{Pb})$; those which form soluble fluorocomplexes ( $\mathrm{Sn}, \mathrm{Al}, \mathrm{Fe}, \mathrm{Si}, \mathrm{Cr}$ ); those that are not oxidized $(\mathrm{Au}, \mathrm{Ag}, \mathrm{Pd})$; those whose fluorides are soluble in the leachate but do not form fluorocomplexes $(\mathrm{Cu}, \mathrm{Ni}, \mathrm{Zn})$. The replacement of $\mathrm{H}_{2} \mathrm{O}_{2}$ by $\mathrm{NaClO}$ moved $\mathrm{Pb}, \mathrm{Au}$ and $\mathrm{Pd}$ to the group of elements which are soluble in the leachate due to the formation of chlorocomplexes. In this aspect, the $\mathrm{HF}+\mathrm{H}_{2} \mathrm{O}_{2}$ mixture was a better leachant than $\mathrm{HF}+$ $\mathrm{NaClO}$ one because all noble metals were concentrated into a very small mass fraction of the original PCB.

This route was developed for PCB from small EEE (cell phones). It is unlikely that this route is applicable to large size PCBs (like motherboards) due to their greater mass, complexity and heterogeneity, thus increasing the cost of a multistage leaching and separation process.

\section{ACKNOWLEDGEMENTS}

The authors would like to thank Council of Technological and Scientific Development (CNPq) for financial support. Walner C. Silva and Roger S. Corrêa acknowledge PIBIC/CNPq-UFRJ for a fellowship.

\section{REFERENCES}

1. Ackil, A.; Erust, C.; Gahan, C. S.; Ozgun, M.; Sahin, M.; Tuncuk., A.; Waste Manage. 2015, 45, 258.

2. Huang, J.; Chen, M.; Chen, H.; Chen, S.; Sun, Q.; Waste Manage. 2014, $34,488$.

3. Hadi, P.; Xua, M.; Lin, C. S. K.; Hui, C. W.; McKay, G.; J. Hazard. Mater. 2015, 283, 234.

4. Sarvar, M.; Salarirad, M. M.; Shabani, M. A.; Waste Manage. 2015, 45, 246.

5. Wang, F.; Zhao,Y.; Zhang, T.; Duan, C.; Wang, L.; Waste Manage. 2015, $43,434$. 
6. Cucchiella, C.; D’Adamo, I.; Koh, S. C. L.; Rosa, P.; Renewable Sustainable Energy Rev. 2015, 51, 263.

7. Vats, M. C.; Singh. S. K.; Waste Manage. 2015, 45, 280.

8. Rubin, R. S.; Castro, M. A. S.; Brandão, D.; Schalch, V.; Ometto, A. R.; J. Cleaner Prod. 2014, 64, 297.

9. Vasile, C.; Brebu, M. A.; Totolin, M.; Yanik, J.; Karayildirim, T.; Darie, H.; Energy Fuels 2008, 22, 1658.

10. Torihara, K.; Kitajima, T.; Mishima, N.; Procedia CIRP 2015, 26, 746.

11. Ghosh, B.; Ghosh, M. K.; Parhi P.; Mukherjee, P. S.; Mishra, B. K.; J. Cleaner Prod. 2015, 94, 5.

12. Riedewald, F.; Gallagher, M. S.; MethodsX 2015, 2, 100.

13. Camelino, S.; Raoa, J.; Padilla, R, L.; Lucci, R.; Procedia Mater. Sci. 2015, 9, 105.

14. Petter, P. M. H.; Veit, H. M.; Bernardes, A. M.; Waste Manage. 2014, 34, 475.

15. Holgersson, S.; Steenari, B. M.; Björkman, M.; Cullbrand, K.; Resour., Conserv. Recycl. 2018, 133, 300.

16. Vats, M. C.; Singh, S. K.; Int. J. Innovative Res. Sci. Eng. Technol. 2014, 3, 16917 .

17. Charles, R. G.; Douglas, P.; Hallin, I. L.; Matthews, I.; Liversage, G.; Waste Manage. 2017, 60, 505.

18. Kaya, M.; Waste Manage. 2016, 57, 64; Ning, C.; Lin, C. S. K.; Hui, D. C. W.; McKay, G.; Top. Curr. Chem. 2017, 375, 43.

19. Jiang, W.; Jia, L.; Ming, X. Z.; J. Hazard. Mater. 2009, 161, 257; Sohaili, J.; Muniyandi, S. K.; Mohamad, S. S.; Int. J. Sci. Eng. Res. 2012, 3,1 .

20. He, J.; Duan, C.; Waste Manage. 2017, 60, 618.

21. Bidini, G.; Fantozzi, F.; Bartocci, P.; D’Alessandro, B.; D’Amico, M.; Laranci, P.; Scozza, E.; Zagaroli, M.; J. Anal. Appl. Pyrolysis 2015, 111, 140.

22. Xiu, F. R.; Weng, H.; Qi, Y.; Yu, G.; Zhang, Z.; Zhang, F. S.; Chen, W.; Waste Manage. 2017, 60, 643.

23. Yang, T.; Zhu, P.; Liu, W.; Chen, L.; Zhang, D.; Waste Manage. 2017, $68,449$.

24. Tuncuk, A.; Stazi, V.; Akcil, A.; Yazici, E. Y.; Deveci, H.; Miner. Eng. 2012, 25, 28.

25. Yazici, E. Y.; Deveci, H.; Int. J. Miner. Process. 2013, 134, 89.

26. Yazici, E. Y.; Deveci, H.; Hydrometallurgy 2013, 139, 30.

27. Sheng, P. P.; Etsell, T. H.; Waste Manage. Res. 2007, 25, 380.

28. Sun, Z. H I.; Xiao, Y.; Sietsma, J.; Agterhuis, H.; Visser, G.; Yang Y.; Hydrometallurgy 2015, 152, 91.

29. Bhat, V.; Rao, P.; Patil, Y.; Procedia - Social and Behavioral Sciences 2012, 37, 397.

30. Hilson, G.; Monhemius, A.J.; J. Cleaner Prod. 2006, 14, 1158.

31. Birloaga, I.; Michelis, I.; Ferella, F.; Buzatu, M.; Vegliò, F.; Waste Manage. 2013, 33, 935.

32. Yamane, L. H.; Moraes, V. T.; Espinosa, D. C. R.; Tenório, J. A. S.; Waste Manage. 2011, 31, 2553

33. Zhou, Y.; Qiu, K.; J. Hazard. Mater. 2010, 173, 823.

34. Feigl, F.; Spot Tests in Inorganic Analysis, Elsevier: Amsterdam, 1958, chap. 3.

35. Lurie, J.; Handbook of Analytical Chemistry, $3^{\text {rd }}$ ed., Mir: Moscow, 1978, chaps. 3, 6 and 10.

36. Cantor, S. E.; Met. Finish. 2009, 107, 58.

37. Adhapure, N. N.; Dhakephalkar, P. K.; Dhakephalkar, A. P.; Tembhurkar, V. R.; Rajgure, A. V.; Deshmukh, A. M.; MethodsX 2014, 1, 181.

38. Raele, M. P.; Pretto, L. R.; Zezell, D. M.; Waste Manage. 2017, 68, 475.

39. Hofmeister, C.; Maa, S.; Flauding, T.; Mayer, T.; Mat. Chem. Phys. 2017, 185, 129.

40. Ribeiro, P. P. M.; Guimarães, Y. F.; Santos, I. D.; Dutra, A. J. B.; Proceedings of the XIIIth International Mineral Processing Symposium, Bodrum, Turkey, 2012, pp. 1009-1016.
41. Roine, A.; HSC Chemistry® ver. 6.1, Outotec Research Oy: Helsinki, 2010.

42. Yen, W. T.; Pindred, R. A.; Lam, M. P. In Advances in Gold and Silver Processing; Fuerstenau, M. C., Hendrix; J. L., eds.; The Society for Mining, Metallurgy and Exploration: Littleton, 1990, p. 67-74.

43. Clever, H. L.; Johnston, F. J.; J. Phys. Chem. Ref. Data 1980, 9, 751.

44. Mohapatra, M.; Anand, S.; Mishra, B. K.; Giles, D. E.; Singh, P.; J. Environ. Manage. 2009, 91, 67.

45. Aktas, S.; Hydrometallurgy 2010, 104, 106.

46. Liu, S.; Liu, R.; Wu, Y.; Wei, Y.; Fang, B.; Energy Procedia 2013, 39, 387.

47. Hoffman Jr., C.; Mensik, J. D.; Riley, L. B.; Determination of Gold in Geological materials by solvent extraction and atomic absorption spectrometry, Geological Survey Circular 544, The US Department of the Interior: Washington, 1968, $12 \mathrm{p}$.

48. Raju, P. V. S.; J. Sci. Ind. Res. 2006, 65, 65.

49. Lamb, A. E.; Anderson, C. W. N.; Haverkamp, R. G.; Chemistry in New Zeland 2001, September, 31.

50. Levin, S.; Krishnan, S.; Rajkumar, S.; Halery, N.; Balkunde, P.; Sci. Total Environ. 2016, 551-552, 101.

51. Li, J; Duan, H.; Yu, K.; Liu, L.; Wang S.; Resour., Conserv. Recycl. 2010, $54,810$.

52. Flame retardants in printed circuit boards, updated draft report. The US Environmental Protection Agency, National Service Center for Environmental Publications: Cincinnati, 2014, 736 p.

53. Verma, H. R.; Singh, K. K.; Mankhand, T. R.; J. Cleaner Prod. 2016, 139, 586.

54. Field, L. D.; Sternhell, S.; Kalman, J. R.; Organic Structures from Spectra, $4^{\text {th }}$ ed., Wiley: Chichester, 2008, chap. 3 and 9; Field, L. D.; Sternhell, S.; Kalman, J. R.; Organic Structures from Spectra, $3^{\text {rd }}$ ed., Mir: Moscow, 1978, chap. 3, 6 and 10.

55. Greenwood, N. N.; Earnshaw, A.; Chemistry of the Elements, $2^{\text {nd }}$ ed., Elsevier Butterworth-Heinemann: London, 2010, chap. 10.

56. Petrucci, R. H.; Harwood, W. S.; Herring, G. E.; Madura, J.; General Chemistry: Principles \& Modern Applications, $9^{\text {th }}$ ed., Prentice Hall: New Jersey, 2007, p. 606.

57. Kumar, M.; Babu, M. N.; Mankhand, T. R.; Pandey, B. D.; Hydrometallurgy 2010, 104, 304.

58. Silvas, F. P. C.; Correa, M. M. J.; Caldas, M. P. K.; Moraes, V. T.; Espinosa, D. C. R.; Tenório, J. A. S.; Waste Manage. 2015, 46, 503.

59. Kinoshita, T.; Akita, S.; Kobayashi, N.; Nii, S.; Kawaizumi, F.; Takahashi, K.; Hydrometallurgy 2003, 69, 73.

60. Oh, C. J.; Lee, S. O.; Yang, H. S.; Ha, T. J.; Kim, M. J. J.; Air Waste Manage. Assoc. 2003, 53, 897.

61. Silva, W. C.; Corrêa, R. S.; Silva, C. S. M.; Afonso, J. C.; Silva, R. S.; Vianna, C. A.; Mantovano, J. L.; Waste Manage. 2018, 78, 781.

62. Pinheiro. A. A. S.; Lima, T. S.; Campos, P. C.; Afonso, J. C.; Hydrometallurgy 2004, 74, 77.

63. Lima, T. S.; Campos, P. C.; Afonso, J. C.; Hydrometallurgy 2005, 80, 211.

64. Portella, K. F.; Rattmann, K. R.; Souza, G. P.; Garcia, C. M.; Cantão, M. P.; J. Mater. Sci. 2000, 35, 3263.

65. Paiva, A. P.; Ortet, O.; Carvalho, G. I.; Nogueira, C. A.; Hydrometallurgy 2017, 171, 394

66. Huang, H.; Huang, C.; Wu, Y.; Ding, S.; Liu, N.; Su, D.; Lv, T.; Hydrometallurgy 2015, 156, 6

67. Marsden, J.; House, I.; The Chemistry of Gold Extraction, $2^{\text {nd }}$ ed., The Society for Mining, Metallurgy and Exploitation: Littleton, 2006, chap. 7.

68. Kyriakalis, G. In Gold Ore Processing - Project Development and Operations, $2^{\text {nd }}$ ed.; Adams, M. D., ed.; Elsevier: Amsterdam, 2016, chap. 47. 